\title{
Nesting habits, alternative nesting tactics and female territoriality of the cockroach-hunting solitary wasp Penepodium luteipenne (Hymenoptera, Sphecidae)
}

\author{
Sandor Christiano Buys' \\ I Laboratório de Biodiversidade Entomológica, Instituto Oswaldo Cruz, Fundação Oswaldo Cruz, Avenida \\ Brasil 4.365, Pavilhão Mourisco, sala 201, Manguinhos, 21.045-900, Rio de Janeiro, RJ, Brazil. \\ Corresponding author: Sandor Buys (sbuys@biologia.ufrj.br; sandor.buys@gmail.com) \\ Academic editor: J. Neff | Received 20 July 2011 | Accepted 27 September 2011 | Published 10 January 2012 \\ Citation: Buys S (2012) Nesting habits, alternative nesting tactics and female territoriality of the cockroach-hunting \\ solitary wasp Penepodium luteipenne (Hymenoptera: Sphecidae). Journal of Hymenoptera Research 24: 27-41. doi: \\ 10.3897/JHR.24.1828
}

\begin{abstract}
The nesting behaviour of the cockroach-hunting solitary wasp Penepodium luteipenne (Fabricius, 1804) is described, including five different nesting tactics: digging of new nests, use of pre-existing burrows in the soil, brood parasitism of open nests, brood parasitism of closed nests, and nest usurpation. Observations of a peculiar female territorial behaviour are also provided. Knowledge of the behaviour of other species of the tribe Podiini is summarized and compared with the behaviour of P. luteipenne. This study is based on nesting females observed in the Biological Reserve of Poço das Antas, an area in southeastern Brazil covered by Atlantic Forest.
\end{abstract}

\section{Keywords}

Behaviour, biology, cleptoparasitism, Podiini

\section{Introduction}

The genus Penepodium Menke, together with the genera Podium Fabricius, Trigonopsis Perty and Dynatus Lepeletier form a monophyletic group of Neotropical cockroachhunting sphecid wasps (Bohart and Menke 1976, Ohl 1996a, b), currently classified as the tribe Podiini (Pulawski 2011a). The biology of the Podiini is known from short 
notes on some species (see Pulawski 2011b) and a few more extensive studies (e.g., Williams 1928, Eberhard 1974, Ribeiro and Garófalo 2010). In the present paper the nesting behaviour of Penepodium luteipenne (Fabricius, 1804) is described, including five alternative nesting tactics and a peculiar female territorial behaviour. Some aspects of the knowledge on the behaviour of the Podiini, especially motor patterns concerning nesting activity, are summarized, and compared with the behaviour of $P$. luteipenne. Larval behaviour and development of P. luteipenne was described by Buys (2009a). The presently studied species (the same as that previously studied by Buys 2001; 2009a; b) may not be the same as the species studied by Williams (1928) in Amazonian Brazil, as P. luteipenne (S.T. Amarante, personal communication). Even so, 1 here use the name P. luteipenne to refer to both of these biological entities, pending the completion of a revisionary study of the genus.

\section{Methods}

The study was carried out in the Biological Reserve of Poço das Antas (20 $30^{\prime}$ S, $42^{\circ} 15^{\prime} \mathrm{W}$; cities of Silva Jardim and Casimiro de Abreu, Rio de Janeiro State), an area in southeastern Brazil covered by the Atlantic Forest. The area was visited every month from December 1994 to February 1997, with additional, sporadic, observations in 2001 and 2002. The complete construction and provisioning of about 90 nests of Penepodium luteipenne was observed, and several other nesting females were observed during various phases of the nesting cycle. Some females were marked with rapid dry enamel to facilitate individual observation. Coloured dots were placed on the dorsum or on the legs of the wasps with a small paintbrush while they were digging or closing their nests. It was almost always possible to mark the wasps without interrupting their activities. Prey items were measured with a micrometer and weighed with a digital balance while still alive. The prey items were put in transparent plastic sacs and carefully compressed in order to immobilize them for measurement. Voucher specimens of adult P. luteipenne and its prey items, as well original field notes and photographs, were deposited in the entomological collection of the Instituto Oswaldo Cruz (Rio de Janeiro, RJ) (Sandor Buys Collection - SB). Additional voucher specimens were deposited at the Museu Nacional - Universidade Federal do Rio de Janeiro (Rio de Janeiro, RJ) and the Museu de Zoologia - Universidade de São Paulo (São Paulo, SP).

\section{Results}

\section{Habitat, nest structure and daily nesting activity}

Nesting females were found at horizontal sites, without litter or low vegetation, on unpaved roads that crossed forested areas. The nests consisted of single celled bur- 
rows $3-5 \mathrm{~cm}$ deep $(\mathrm{n}=15)$, with a narrower entrance tunnel $5-10 \mathrm{~mm}$ in height $(\mathrm{n}=5)$. In cross section, the cells were circular with $12-15 \mathrm{~mm}(\mathrm{n}=8)$ in diameter, and the entrance tunnels were elliptical, the major axis with $9-12 \mathrm{~mm}(\mathrm{n}=16)$ and the minor axis with $6.5-8.5 \mathrm{~mm}(\mathrm{n}=16)$. Females usually appeared on the nesting site between 8:00-10:00 hrs and ceased activity from 16:00-18:00 hrs. They commonly remained rested on the ground at sites exposed to the sun before initiating activity, presumably to warm up.

\section{Nesting site selection}

Females selecting a nest site initially walked on the ground antennating the soil. They initially dug in several sites, and inspected crevices and other soil irregularities with their mandibles. Occasionally they entered nests of conspecific females or, more rarely, the nests of other ground-nesting wasp species. Usually, the females dug a number of short burrows before digging a nest. They did not close these abandoned tentative burrows.

\section{Digging of new nests}

When digging a nest a female Penepodium luteipenne cut the soil with her mandibles, accumulating lumps of earth in their mouthparts. She then stepped aside about 2-4 $\mathrm{cm}$ and tossed the earth a short distance with a flip of her head. A female would dig from opposite sides on the same axis. After digging for a few minutes on one side, she turned $180^{\circ}$ and continued the excavation on the opposite side. The excavated earth thus formed two semi-circular mounds around the nest entrance (Fig. 1). Females periodically interrupted their excavations and left to gather water, which they regurgitated on the excavation site, apparently to soften the earth.

\section{Nesting in pre-existing burrows in the ground}

Female Penepodium luteipenne commonly reused pre-existing burrows. These almost always were old nests of conspecific females. The females usually found the old nests partially filled with earth, the remains of prey, and an empty cocoon. They spent some time excavating the burrows to recondition them. Although it was not possible to securely define the frequency of reuse of pre-existing burrows during this study, I estimate at least $25 \%$ of the observed nests were reused nests of conspecifics, and quite possibly more. Reused nests were recognisable because remains of cockroaches and the characteristic cocoons of P. luteipenne (see Buys 2001, 2009 for cocoon morphology) were found in the mounds of excavated earth left around the entrance. 


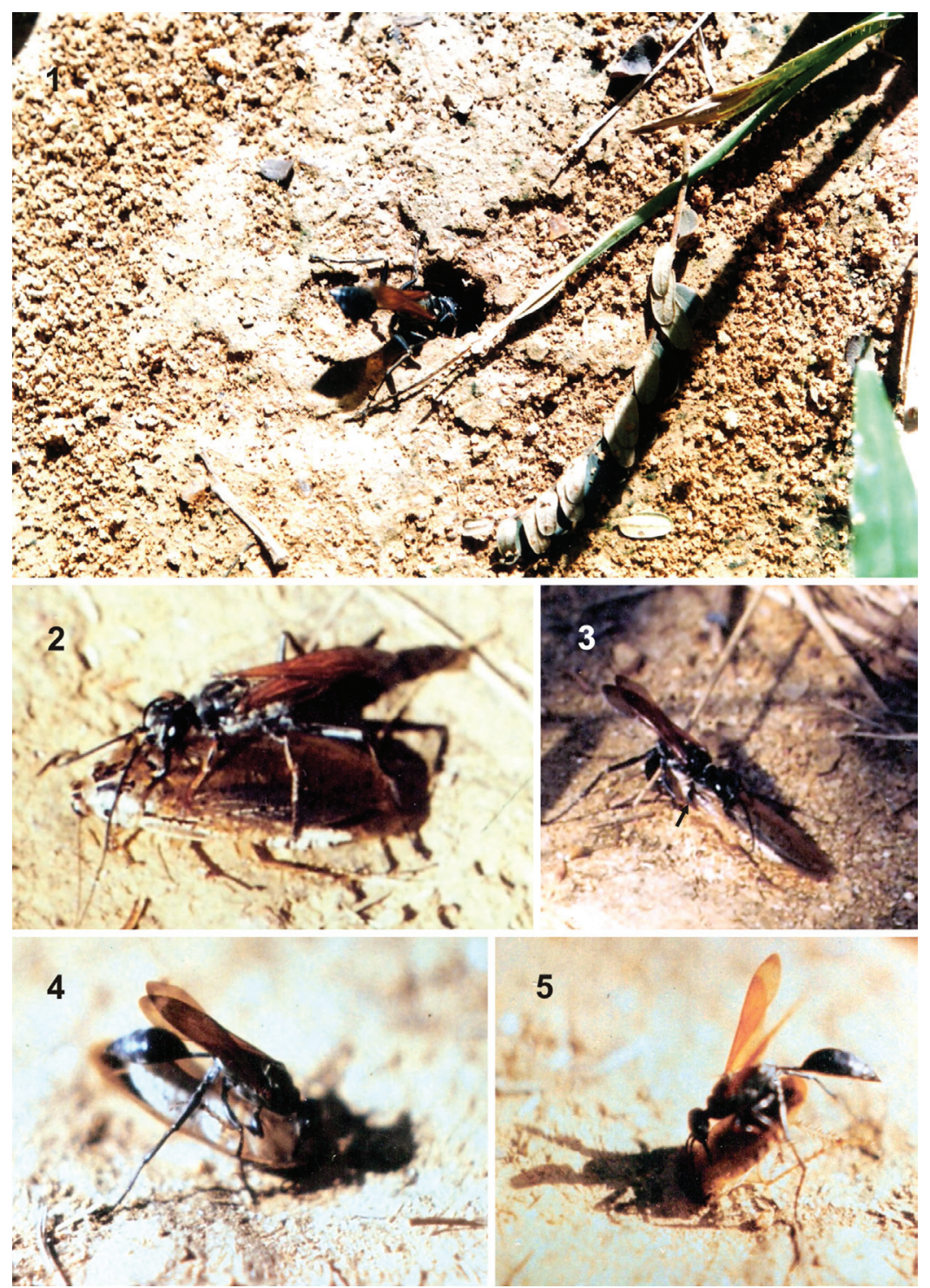

Figures I-5. Nesting behaviour of Penepodium luteipenne I Digging of the nest, the accumulated lose earth around the nest entrance is the earth excavated from the burrow $\mathbf{2}$ stinging of the prey $\mathbf{3}$ oviposition (setae in the wasp's front leg) $\mathbf{4}$ placement of the prey into the nest $\mathbf{5}$ female pushing a prey stuck in the nest entrance, using both the front and mid legs, and the opened mandibles.

\section{Brood parasitism in open nests}

Brood parasitism in open nests was observed twice. In the first case the female entered the nest of another female while she was absent and found prey items. She reacted quickly, moving her body and antennae, and performed the following behavioural sequence: (1) grasped one cockroach with her mandibles, (2) pulled the cockroach 
outside the burrow, (3) stung it, (4) ate the egg of the host wasp, (5) laid her egg on the prey, (6) reinserted the cockroach into the nest and (7) departed. The host female later closed the nest apparently without perceiving the violation of her nest.

In the second case, the female followed the same behavioural sequence described above, but differed in that when she checked the base of the forelegs of the prey taken from the nest she did not find an egg of the host female, she laid her own egg on the prey and departed. Later the host female arrived at the nest with one more prey item and oviposited on it. The parasitized nest was thus left with two prey items bearing eggs.

\section{Brood parasitism in closed nest}

Brood parasitism in closed nests was observed three times. The cleptoparasitic females found recently closed, provisioned nests of other females. They opened the nest plug and followed the same behavioural sequence described above for brood parasitism in open nests (inclusive of eating the host egg), with the additional step that the cleptoparasitic female closed the nest herself.

\section{Nest usurpation}

Effective nest usurpation was observed only once, but agonistic behaviour among nesting females that apparently were attempts at nest usurpation was often observed. In the one unequivocal case of nest usurpation, the usurping female repeatedly approached a nesting female, who had been marked with enamel on one leg. Both wasps reacted aggressively, charging each other and sometimes rolling with each other on the ground. The resident female had placed two prey items into the nest, one of them with her egg, but she finally abandoned the nest, apparently due to the persistent aggression of the usurping female. The usurping female did not remove the original prey items from the nest but instead placed two more cockroaches in the nest, on one of which she laid an egg. The nest was thus left with four prey items, two of which bore eggs.

\section{Nest provisions}

The prey items from 64 nests were collected: 31 nests with one prey item, 23 nests with two prey items, seven nests with three prey items, and three nests with four prey items. A total of 109 epilamprine cockroaches (Blattodea: Blaberidae) was collected from the nests: 19 adults of Poeciloderrhis catharina (Shelford, 1910); 10 adults of P. basistriga (Walker, 1868); five adults of Poeciloderrhis sp.; 69 nymphs probably of $P$. catharina; and six nymphs probably of $P$. basistriga. Morphometric features taken from live prey items are summarized Table 1. 
Table I. Length, width and biomass of prey species found in nests of Penepodium luteipenne (minimum, mean and maximum in millimetre).

\begin{tabular}{|c|c|c|c|c|c|c|}
\hline & Length & $\mathrm{N}$ & Width & $\mathrm{N}$ & Biomass (g) & $\mathrm{N}$ \\
\hline Poeciloderrhis catharina & (21.7) $24.3(25.5)$ & 08 & (10.4) $11.0(12.2)$ & 08 & $(0.26) 0.40(0.68)$ & 19 \\
\hline Poeciloderrhis basistriga & (14.0) $18.1(25.0)$ & 05 & (07.0) 9.7 (11.8) & 05 & $(0.13) 0.30(0.46)$ & 08 \\
\hline Epilampra sp. & (23.1) $24.5(26.0)$ & 02 & (10.0) $10.6(11.3)$ & 02 & $(0.15) 0.26(0.37)$ & 02 \\
\hline $\begin{array}{l}\text { Nymph type } 1 \\
\text { (P. catharind ?) }\end{array}$ & (13.0) $18.3(27.5)$ & 46 & (06.0) $10.2(12.0)$ & 46 & (0.09) $0.21(0.36)$ & 66 \\
\hline $\begin{array}{l}\text { Nymph type } 2 \\
\text { (P. basistriga?) }\end{array}$ & (17.5) $17.9(18.3)$ & 02 & (09.5) $09.6(09.7)$ & 02 & $(0.16) 0.25(0.36)$ & 05 \\
\hline
\end{tabular}

\section{Prey transport}

When transporting prey, a female Penepodium luteipenne initially grasped the antennae of the cockroach with her mandibles and dragged it, its body on ground, while walking forwards. The prey remained under the wasps' body, usually venter up. The females sometimes flew while carrying their prey, but the flights were rather clumsy and usually only in straight lines. On these occasions, a female would grasp the antennae of its prey with her mandibles and appeared to hold its body with her legs. The length of the flights seemed to be related to the distance of the prey from the nest and to the size of the prey. Usually longer distances were traversed in flight, especially when it is necessary to pass over areas with vegetation or abundant litter. On the other hand, the females had difficulty flying with larger prey items, so flight length decreased with increasing prey size. Thus, large prey items usually were carried on the ground or with a set of short flights, while small prey items were commonly carried by long flights.

\section{Prey paralysis}

The duration of the effects of the wasp's venom on its prey was relatively brief as cockroaches collected from nests just after closure were able to walk. Although the prey items transported by females apparently are always under the effect of its venom, suggesting that they sting the prey during the hunt, a female commonly stung again its prey at the nest site before placing it into the burrow. When stinging its prey a female grasped the pronotum of the cockroach with her mandibles, and stung the roach in different points on the ventral surface of its body (Fig. 2). Small prey specimens were immediately paralysed after the sting but females frequently needed to repeatedly sting larger prey items to subdue them before ovipositing on their body and placing them in the nest. 


\section{Oviposition}

A female laid its egg on its prey before inserting it into the nest. This usually was done within $20 \mathrm{~cm}$ of the entrance. Oviposition involved the following stereotypical behavioural sequence (Fig. 3): (1) the paralysed cockroach is placed dorsal side up; (2) the female wasp faces the cockroach; (3) she grasps the cockroach with her front and/or the mid legs; (4) she extends her hind legs, raising the anterior portion of the prey in a manner so that the prey body makes an acute angle to the ground; (5) she bends her gaster so that the tip of her metasoma reaches the region between the forelegs of the cockroach; and finally (6) oviposits behind one forecoxa. The eggs were always laid on the last prey item brought to the nest. Oviposition on this sheltered place probably reduces the probability of the cockroach dislodging the egg when it wakes from paralysis.

\section{Placement of the prey into the nest}

The females inserted the prey into the nest with its head inward. They positioned the head of the cockroach at the nest entrance and, extending their long hind legs, pushed the prey into the nest (Figs 4-5). The females use their front legs and mandibles to manipulate the prey, and their hind legs to maintain their own body on the ground (Figs 4-5). The cockroaches were difficult to maneuver within the nest because their widths were almost as broad as that of the nest cells (see Table 1). Frequently, the width of the cockroach was too large and they became stuck in the nest entrance. On these occasions, the females usually spent a long time attempting to push the prey into the nest. The wasp pushed with its mandibles open, using both its front and mid legs as well as vigorously beating its wings, apparently to increase its strength (Fig. 5). If this attempt failed, they tried to pull the cockroach out by grasping one of its legs, wings or the tip of its abdomen. If this was unsuccessful, they alternated pushing and pulling the prey. A total of 28 abandoned nests were found with cockroaches stuck in the entrance, some of these bearing a wasp's egg.

\section{Nest closure and transport of water}

Females quarried lumps of earth in the ground, usually from within $15 \mathrm{~cm}$ of the nest entrance, and accumulated them in their mouthparts when closing their nests. The females carefully selected the site to quarry the earth, avoiding very compacted earth. They apparently were unable to accumulate loose soil in their mouthparts as they rarely used the loose soil near the entrance left from the nest excavation when closing their nests. On one occasion, a female was observed regurgitating water on loose earth 
which allowed her to accumulate the moistened soil in her mouthparts. The females placed the lumps of earth on the nest entrance without loosening them. They then regurgitated water, dissolving the earth lumps so that they perfectly fit the nest entrance. While females regurgitated water, their entire body vibrated, and they emitted a characteristic pulsing, buzzing sound. These vibrations apparently aided in dissolving the soil. Sometimes females returned repeatedly to the same site to quarry earth, but they did not form distinguishable accessory burrows. Sometimes the females removed little stones and leaf fragments that came with the lump of earth, after they placed the lumps on the nest entrance. Female wasps were often observed gathering water from the central tanks of bromeliads (Bromeliaceae) within five meter from the nest, but the most of the time it was not possible to determine the sources of water because they were in inaccessible places inside the forest. One female was observed collecting water in a temporary rain pool in an unpaved road while another female gathered water accumulated in a dried leaf fallen on the midst of a road, $175 \mathrm{~cm}$ from her nest. Females commonly used the same water sources when digging and closing multiple, successively constructed nests.

During nest closure a female made $10-13$ flights $(n=15)$ to gather water. Each load of water was used to wet 4-8 lumps of earth $(n=15)$. After the nest plug became level with the surface of the ground, the females usually added smaller lumps of earth, which they did not wet, and then placed over the nest entrance fallen leaves, chips, small stones, lumps of dried earth or other debris collected near to the nest. This made the nest entrance visually indistinguishable from the surrounding soil. On one occasion, a female regurgitated a few drops of water soon after concluding the nest closure, apparently to discard excess water. Females never made temporary nest closures. Some nests remained open through the night despite containing prey items.

\section{Defence of the nest}

Females of Penepodium luteipenne drove away other insects, both those walking within about $20-30 \mathrm{~cm}$ of the nests, and flies hovering over the nest entrance, throughout the nesting cycle. Females with open mandibles aggressively charged small objects (such as a stylus) placed near open nests. However, females did not defend nests after closing them. Several times nests were excavated to collect the prey items immediately after closure and the nearby female did not react.

\section{Defence of the nesting site}

Female Penepodium luteipenne typically dig a series of single celled nests, each within $5-50 \mathrm{~cm}$ of one another. Occasionally during the nest cycle a female would traverse the site where she had constructed several nests and aggressively charge any other wasps she encountered, conspecific or not. This behaviour allowed her to monopolize 
a particular nest area. This defensive behaviour was observed primarily during the following phases of the nesting cycle: (1) searching for a nesting site; (2) nest digging, when females often interrupted digging to walk around the nest site on repetitive routes; (3) foraging, when the female returned to the nest without prey, she usually checked the nest interior, and then walked about the nest site. Aggressive encounters among conspecific females were most frequent, but females of P. luteipenne also attacked other species such as Eremnophila binodis (Fabricius, 1789) (Sphecidae), Trypoxylon aestivale Richards, 1934 (Crabronidae), Cerceris sp. (Crabronidae), and Pepsis sp. (Pompilidae).

\section{Discussion}

\section{Nest provisions}

The prey species and number of prey items per nest in the tribe Podiini is summarized in the Table II. As a rule, Podiini use cockroaches to provision their nests, but crickets (Orthoptera: Gryllidae) were reported as prey of Trigonopsis grylloctonus Richards, 1937 (Richards 1937: unidentified grylids) and Trigonopsis rufiventris (Fabricius, 1804) (Vardy 1978: Anaxipha sp.) (Table 2). Females of the genera Penepodium and Dynatus, in general, use larger prey species than females of the genera Podium and Trigonopsis (Table 2).

\section{Temporary closing of the nest}

Penepodium luteipenne is similar to some other Podiini who do not construct temporary nest plugs [Penepodium haematogastrum (Spinola, 1851): Williams 1928; Podium rufipes Fabricius, 1805: Krombein 1970]. However, some other Podiini have been observed constructing temporary nest closures when nest provisioning is not completed in one day [Trigonopsis cameronii (Kohl, 1902): Eberhard 1974; Podium denticulatum F. Smith, 1856: Ribeiro and Garófalo 2010]. Penepodium luteipenne leave their nests open even on occasions when provisioning is not completed in one day.

\section{Prey paralysis}

Temporary paralysis of prey, as described here for Penepodium luteipenne, has been observed in several previously studied species of the genus [P. fumipenne (Taschenberg, 1869): Genise 1981; P. gorianum (Lepeletier de Saint Fargeau, 1845): Garcia and Adis 1993; P. latro (Kohl, 1902): Buys 2006; and Amazonian P. luteipenne: Williams 1928]. However, species of Podium and Trigonopsis seem to more permanently paralyze their prey (P. fulvipes Cresson, 1865: Genaro 1994; P. luctuosum 
Table 2. Summary of prey species and number of prey items per nest in species of the tribe Podiini.

\begin{tabular}{|c|c|c|c|}
\hline Podiini species & Prey species & $\begin{array}{l}\text { Prey items } \\
\text { per cell }\end{array}$ & Source \\
\hline \multirow[t]{2}{*}{ Dynatus nigripes } & $\begin{array}{l}\text { Eublaberus distanti (Kirby, 1903) } \\
\text { Archimandrita tessellata (Rehn, 1903) }\end{array}$ & 15 & Kimsey 1978 \\
\hline & Hyporhicnoda (or near genus) & 7 & Cooper 1980 \\
\hline $\begin{array}{l}\text { Penepodium fumi- } \\
\text { penne }\end{array}$ & Unidentified cockroaches & 4 & Genise 1981 \\
\hline $\begin{array}{l}\text { Penepodium goria- } \\
\text { num }\end{array}$ & Eunyctibora sp. & $1-4$ & $\begin{array}{l}\text { Garcia and } \\
\text { Adis } 1993\end{array}$ \\
\hline Penepodium latro & Poeciloderrhis sp. & 1 & Buys 2006 \\
\hline \multirow{3}{*}{$\begin{array}{l}\text { Penepodium lu- } \\
\text { teipenne }\end{array}$} & $\begin{array}{l}\text { Poeciloderrhis basistriga (Walker, 1868) } \\
\text { Poeciloderrhis catharina (Shelford, 1910) }\end{array}$ & $1-4$ & $\begin{array}{l}\text { Buys 2001, } \\
\text { 2009a }\end{array}$ \\
\hline & Epilampra abdomennigrum (De Geer, 1773) & - & Williams 1928 \\
\hline & Epilampra abdomennigrum (De Geer, 1773) & $1-5$ & Richards 1937 \\
\hline Podium luctuosum & Parcoblatta ubleriana (Saussure, 1862) & $5-7$ & $\begin{array}{c}\text { Krombein } \\
1967\end{array}$ \\
\hline \multirow{2}{*}{$\begin{array}{l}\text { Podium denticu- } \\
\text { latum }\end{array}$} & $\begin{array}{c}\text { Cahita borero Rehn, } 1937 \\
\text { Pseudomops neglecta Shelford, } 1906\end{array}$ & $2-11$ & $\begin{array}{c}\text { Camilo et al. } \\
1996\end{array}$ \\
\hline & Unidentified cockroaches & $2-10$ & $\begin{array}{c}\text { Ribeiro and } \\
\text { Garófalo } 2010\end{array}$ \\
\hline Podium fulvipes & $\begin{array}{c}\text { Euthlastoblatta spp. } \\
\text { Cariblata sp. } \\
\text { Latiblattella rehni Herbard, } 1917 \\
\text { Epilampra sp. } \\
\text { Plectoptera sp. }\end{array}$ & - & Genaro 1994 \\
\hline \multirow{3}{*}{ Podium rufipes } & Parcoblatta pennsylvanica (De Geer, 1773) & $1-3$ & Rau 1937 \\
\hline & $\begin{array}{c}\text { Chorisoneura texensis Saussure \& Zehntner, } 1893 \\
\text { Cariblatta lutea Saussure \& Zehntner, } 1893 \\
\text { Latiblattella rehni Herbard, } 1917 \\
\text { Parcoblatta sp. } \\
\text { Cariblatta minima Herbard, 1916 } \\
\text { Eurycotis floridana (Walker, 1868) }\end{array}$ & $3-6$ & $\begin{array}{l}\text { Krombein } \\
1967\end{array}$ \\
\hline & $\begin{array}{c}\text { Chorisoneura texensis Saussure \& Zehntner, } 1893 \\
\text { Latiblattella rehni Herbard, } 1917 \\
\text { Chorisoneura sp. } \\
\text { Eurycotis floridana (Walker, 1868) }\end{array}$ & $1-3$ & $\begin{array}{l}\text { Krombein } \\
1970\end{array}$ \\
\hline $\begin{array}{l}\text { Trigonopsis came- } \\
\text { ronii }\end{array}$ & $\begin{array}{c}\text { Riatia fulgida (Saussure, 1862) } \\
\text { Chorisoneura translucida (Saussure, 1864) } \\
\text { Amazonina sp. }\end{array}$ & $8-15$ & Eberhard 1974 \\
\hline $\begin{array}{l}\text { Trigonopsis cyclo- } \\
\text { cephalus }\end{array}$ & Poroblatta sp. & - & Vardy 1978 \\
\hline $\begin{array}{l}\text { Trigonopsis gryl- } \\
\text { loctonus }\end{array}$ & Unidentified crickets (Orthoptera: Gryllidae) ${ }^{1}$ & - & Richards 1937 \\
\hline $\begin{array}{l}\text { Trigonopsis rufiven- } \\
\text { tris }\end{array}$ & $\begin{array}{c}\text { Anaxipha sp. }\left(\text { Orthoptera: }{\text { Gryllidae })^{2}}\right. \\
\text { Chorisoneura sp. } \\
\text { Anaplecta sp. } \\
\text { Calhypnorna sp. }\end{array}$ & - & Vardy 1978 \\
\hline
\end{tabular}

1,2 These are unique cases of non-cockroach prey items found in Podiini nests 
Smith, 1856: Krombein 1967; P. rufipes: Krombein 1967, 1970; and T. cameronii: Eberhard 1974).

\section{Oviposition on the last hunted prey item}

Oviposition on the first prey item stored in the nest has been observed among most of the Podiini studied to date (Penepodium gorianum: Garcia and Adis 1993; Podium denticulatum: Ribeiro and Garófalo 2010; Podium rufipes: Krombein 1970; and Trigonospis cameronii: Eberhard 1974). Only P. luteipenne, in this study, and the Amazonian P. luteipenne studied by Williams (1928), oviposit on the last hunted prey item.

\section{Oviposition posture}

The stereotypic oviposition posture observed in Penepodium luteipenne is similar to that of Penepodium haematogastrum, as illustrated by Williams (1928: fig. 188), and of Trigonospis cameronii, as illustrated by Eberhard (1974: fig. 4). However, the prey items used by $T$. cameronii are much smaller than those used by $P$. luteipenne and P. haematogastrum, and it uses only its front legs to hold its prey (see Eberhard 1974: fig. 4).

\section{Oviposition outside the nest}

Penepodium luteipenne, as well as other Podiini (Amazonian P. luteipenne: Williams 1928, T. cameronii: Eberhard 1974), is distinct in ovipositing on its prey outside the nest. An exception was observed by Ribeiro and Garófalo (2010) who found that $P$. denticulatum oviposited sometimes before and sometimes after placing its prey in the nest. The behaviour of ovipositing outside the nest may be due to the lack of space inside the nest such that the female cannot assume the characteristic oviposition posture necessary for her to oviposit on a forecoxa of her prey.

\section{Placement of the egg on the prey body}

Placement of the egg under one prey forecoxa, as described for Penepodium luteipenne, was found in previously studied species of Podiini [Dynatus nigripes (Westwood, 1852): Cooper 1980, Kimsey 1978; Amazonian Penepodium luteipenne: Williams 1928; P. gorianum: Garcia and Adis (1993); P. latro: Buys 2006; Podium denticulatum: Camilo et al. 1996, Ribeiro and Garófalo 2010; P. luctuosum: Krombein 1967; P. rufipes: Krombein 1970; Trigonopsis rufiventris: Willliams 1928, Arlé 1933]. Garcia and Adis (1993) and Cooper (1980) observed, in P. gorianum and D. nigripes respectively, that the position of the egg under one forecoxa of the prey prevents the cockroaches from 
dislodging the eggs. Furthermore, Podiini larvae partially penetrate the prey body at the point where the egg is laid and remain immobile during early development (Williams 1928, Krombein 1970, Garcia and Adis 1993, Buys 2009). This point must be a suitable place for the early instar larva to penetrate the prey and feed. Interestingly, the cockroach-hunting crabronid wasps (Hymenoptera: Crabronidae) Tachysphex fanuiensis Cheesman, 1928 (Williams 1945) and Tachysphex inconspicuus (W.F. Kirby, 1890) (Buys 2007) also lay their eggs under one prey forecoxa just as do the Podiini. This can be interpreted as an adaptive convergence.

\section{Position of the prey inside the nest}

Placement of the prey headfirst into the nest as observed in Penepodium luteipenne, was also found in all previously studied species of Podiini (Penepodium gorianum: Garcia and Adis 1993; Podium denticulatum: Camilo et al. 1996; P. fulvipes: Genaro 1994; P. rufipes: Krombein 1970; P. luctuosum: Krombein 1967; and Trigonopsis cameronii: Eberhard 1974). In P. luteipenne, the position of the prey inside the nest, coupled with the elliptical shape of the nest opening tunnel, which is narrower than the cell, apparently aids in preventing the cockroaches from escaping from the open nests after waking from paralysis.

\section{Alternative nesting tactics}

Intraspecific parasitism has been recorded for relatively few species of sphecid wasps (review in Field 1992b, see also Bohart and Menke 1976). However, as more detailed behavioural studies are performed on sphecid wasps, including observations with individually marked females, a number of distinct types of intraspecific parasitism have been found. Intraspecific parasitism may be widespread among sphecids, but it currently remains veiled by the paucity of studies. This seems to be the case for the tribe Podiini, in which distinct types of intraspecific parasitism were observed in Penepodium luteipenne and Trigonopsis cameroni, two species with detailed studies including individually marked females.

\section{Female territoriality}

The defensive behaviour of the females of Penepodium luteipenne at their nests can be interpreted as territorial because they monopolize their nesting sites and defend them against other wasps. Female territorial behaviour has been rarely observed among sphecids or related families. Territorial behaviour identical to those of P. luteipenne was observed in the ammophiline caterpillar-hunting wasp Podalonia valida (Cresson, 1865) (Hymenoptera: Sphecidae) (Steiner 1975) and in the spider-hunting Anoplius viaticus (Linnaeus, 
1758) (Hymenoptera: Pompilidae) (Field 1992a). As these three species belong to distantly related lineages, this behaviour appears to be convergently evolved in these species. The evolution of this kind of territorial behaviour in P. luteipenne may be correlated with monopolization of an area rich in resources and defence of the nest against intraspecific parasitism. The nesting habitat of P. luteipenne is structurally complex, being composed of integrated parts with valuable resources relatively near one another. These include sites where the females search for suitable soil to dig (bare portions of compacted mud soil), sources of water (central cups of bromeliads), and prey items (areas covered with litter where the females can finds cockroaches). Although each of these resources may separately be locally common, a site with all these resources available nearby may not be easily found. At the same time, several clustered nests of one female could represent a form of resource concentration to cleptoparasitic conspecific wasps against which resident females must defend their nest areas. It is thus probable that once a female finds a suitable site, it will be advantageous to maintain it for some time, despite the energetic costs of defending it.

\section{Acknowledgement}

I thank Sérvio Túlio Amarante for identifying Penepodium luteipenne and for sharing unpublished information from his revisionary study on the genus Penepodium, Sônia Fraga and Edivar de Oliveira for identifying the cockroaches, Maria Teresa Benavides Jacobs, Fernando Ferraz, Antônio Squeira-Campos and Flávia Nogueira de Sá for their kindly assistance with field and laboratory work. The manuscript was improved with the valuable comments and corrections by Kevin O'Neill and an anonymous reviewer. I especially thank Jack Neff for kindly revising carefully my English translation of the manuscript, correcting a not-small number of linguistic and grammatical errors. I also thank the Instituto Brasileiro do Meio Ambiente e Recursos Naturais Renováveis (IBAMA) for a license to work and collect in the Biological Reserve of Poço das Antas and the Fundação Carlos Chagas Filho de Amparo à Pesquisa do Estado do Rio de Janeiro (FAPERJ) for a post-doctoral grant.

\section{References}

Arlé R (1933) Sobre a nidificação, a biologia e os parasitos de Sceliphron (Trigonopsis) abdominalis, Petry. Anais da Academia Brasileira de Ciências 5: 205-212.

Bohart RM, Menke AS (1976) Sphecidae wasps of the world: a generic revision. University of California Press, 665 pp.

Buys SC (2001) Last instar larva of Penepodium dubium (Hymenoptera: Sphecidae). Revista de Biología Tropical 49 (1): 327-330.

Buys SC (2006) Observations on the biology and description of the last instar larva of Penepodium latro (Kohl, 1902) (Hymenoptera, Sphecidae). Arquivos do Museu Nacional 64: $121-124$. 
Buys SC (2007) Comparative behavioural study of Tachysphex inconspicuus (Hymenoptera: Crabronidae) in two locations in the southeast Brazil. Neotropical Entomology 3: 327330. doi: 10.1590/S1519-566X2007000300001

Buys SC (2009a) Larval behaviour and development of Penepodium luteipenne (Fabricius, 1804). Mitteilungen des Internationalen Entomologischen Vereins 34: 33-40.

Buys SC (2009b) Sphecidae (Hymenoptera: Apoidea) of Rio de Janeiro State (Southeast Brazil): inventory of species and notes on biology and distribution. Arquivos do Museu Nacional 67: 275-282.

Camillo E, Garófalo CA, Assis JMF, Serrano JC (1996) Biologia de Podium denticulatum Smith em ninhos armadilhas (Hymenoptera: Sphecidae: Sphecinae). Anais da Sociedade Entomológica Brasileira 25: 439-450.

Cooper M (1980) Notes on the biology of Dynatus nigrepes (West.) and Penepodium albovillosum (Cam.) (Hym., Sphecidae). Entomologist's Monthly Magazine 116: 87-89.

Eberhard WG (1974) The natural history and behaviour of the wasp Trygonopsis cameronii Kohl (Sphecidae). Transactions of the Royal Entomological Society of London 125: 295-328. doi: 10.1111/j.1365-2311.1973.tb00545.x

Field J (1992a) Intraspecific parasitism and nest defence in the solitary pompilid wasp Anoplius viaticus (Hymenoptera: Pompilidae). Journal of Zoology 228: 341-350. doi: 10.1111/ j.1469-7998.1992.tb04613.x

Field J (1992b) Intraspecific parasitism as an alternative reproductive tactic in nest-building wasps and bees. Biological Reviews 67: 79-127. doi: 10.1111/j.1469-185X.1992. tb01659.x

Garcia MVB, Adis J (1993) On the biology of Penepodium goryanum (Lepeletier) in wooden trap-nests (Hymenoptera, Sphecidae). Proceedings of the Entomological Society of Washington 95: 547-553.

Genaro JA (1994) Inquilinos de Sceliphron assimile, con enfase en Podium fulvipes (Hymenoptera: Vespidae, Sphecidae, Megachilidae). Caribbean Journal of Science 30: 270-272.

Genise JF (1981) Utilización de excrementos de herbivoros en la nidificación de Penepodium fumipenne (Tacsh.) (Hymenoptera, Sphecidae). Ecosur 8: 51-52.

Kimsey LS (1978) Nesting and male behavior in Dynatus nigripes spinolae (Lepeletier) (Hymenoptera, Sphecidae). Pan-Pacific Entomologist 54: 65-68.

Krombein KV (1967) Trap-nesting Wasps and Bees: Life Histories, Nests and Associates. Smithsonian Institute Press, 570 pp. doi: 10.5962/bhl.title.46295

Krombein KV (1970) Behavioral and life-history notes on three Floridian solitary wasp (Hymenoptera: Sphecidae). Smithsonian Contributions to Zoology 46: 1-26. doi: 10.5479/ si.00810282.46

Ohl M (1996a) Die phylogenetischen Beziehungen der Sphecinae (Hymenoptera: Apoidea: "Sphecidae") aufgrund morphologischer Merkmale dos Exosckellets. Zoologische Beiträge, Neue Folge 37: 3-40.

Ohl M (1996b) The Phylogenetic Relationships within the Neotropical Podiinae with Special Reference to Podium Fabricius (Hymenoptera: Apoidae: "Sphecidae"). Deutsche Entomologische Zeitschrift 43: 189-218. doi: 10.1002/mmnd.19960430204 
Pulawski WJ (2011a) Family group names and classification. Available from http://www.calacademy.org/research/entomology/Entomology_Resources/Hymenoptera/Sphecidae/ Family_group_names_and_classification.pdf [accessed on 16.06.2011]

Pulawski WJ (2010b) Catalog of Sphecidae sensu lato. Available from: http:/www.calacademy. org/research/entomology/Entomology_Resources/Hymenoptera/sphecidae/Genera_and_ species_PDF/introduction.htm [accessed on 12.07.2011]

Rau P (1937) A note on the nesting habits of the roach-hunting wasp Podium (Parapodium) carolina Rohwer. Entomological News 48: 91-94.

Ribeiro F, Garófalo CA (2010) Nesting behavior of Podium denticulatum. Neotropical Entomology 39: 885-891. doi: 10.1590/S1519-566X2010000600006

Richards OW (1937) Results of the Oxford University expedition to British Guiana, 1929. Hymenoptera, Sphecidae and Bembecidae. Transactions of the Royal Entomological Society of London 86: 101-118. doi: 10.1111/j.1365-2311.1937.tb00427.x

Steiner AL (1975) Description of the territorial behaviour of Podalonia valida (Hymenoptera, Sphecidae) females in southwest Arizona, with remarks on digger wasp territorial behaviour. Quaestiones Entomologicae 11: 113-127.

Vardy CR (1978) A revision of the Neotropical wasp genus Trigonopsis Perty (Hymenoptera: Sphecidae). Bulletin of the British Museum of Natural History (Entomology) 37: 117152.

Williams FX (1928) Studies in tropical wasps - their host and associates. Bulletin of the Experimental Station of Hawaiian sugar Planter's Association (Entomological Series) 19: 1-179.

Williams FX (1945) The aculeate wasps of New Caledonia, with natural history notes. Proceedings of the Hawaiian Entomological Society 12: 407-452. 